\title{
Novel polymorphic microsatellite markers developed for a common reef sponge, Stylissa carteri
}

\author{
Emily C. Giles • Pablo Saenz-Agudelo • \\ Michael L. Berumen • Timothy Ravasi
}

Received: 15 December 2012 /Revised: 9 March 2013 / Accepted: 11 March 2013 /Published online: 4 April 2013

(C) The Author(s) 2013. This article is published with open access at Springerlink.com

\begin{abstract}
Despite the ubiquitous role sponges play in reef ecosystem dynamics, little is known about population-level connectivity in these organisms. The general field of population genetics in sponges remains in its infancy. To date, microsatellite markers have only been developed for few sponge species and no sponge population genetics studies using microsatellites have been conducted in the Red Sea. Here, with the use of next-generation sequencing, we characterize 12 novel polymorphic loci for the common reef sponge, Stylissa carteri. The number of alleles per loci ranged between three and eight. Observed heterozygosity frequencies $(\mathrm{Ho})$ ranged from 0.125 to 0.870 , whereas expected $(\mathrm{He})$ heterozygosity frequencies ranged from 0 . 119 to 0.812 . Only one locus showed consistent deviations from Hardy-Weinberg equilibrium (HWE) in both populations and two loci consistently showed the possible presence of null alleles. No significant linkage disequilibrium was detected for any pairs of loci. These microsatellites
\end{abstract}

Emily C. Giles and Pablo Saenz-Agudelo these authors contributed equally to this work.

E. C. Giles $(\bowtie) \cdot$ T. Ravasi

Division of Biological and Environmental Sciences and

Engineering and Division of Applied Mathematics and Computer

Science, King Abdullah University of Science and Technology,

Thuwal 23955, Saudi Arabia

e-mail: emily.giles@kaust.edu.sa

P. Saenz-Agudelo $\cdot$ M. L. Berumen

Red Sea Research Center, King Abdullah University of Science

and Technology, Thuwal 23955, Saudi Arabia

\section{L. Berumen}

Biology Department, Woods Hole Oceanographic Institution,

Woods Hole, MA 02543, USA

T. Ravasi

Department of Medicine, Division of Medical Genetics, University

of California, San Diego, 9500 Gilman Drive La Jolla,

San Diego, CA 92093, USA will be of use for numerous ecological studies focused on this common and abundant sponge.

Keywords Microsatellites · Sponges · Population genetics · Connectivity $\cdot$ Stylissa carteri

\section{Introduction}

In the field of benthic reef ecology, considerable effort has been made to study coral population dynamics (Van Oppen and Gates 2006; Davies et al. 2012), while sponge ecology and population genetics remain in their infancy (Becerro 2008; Uriz and Turon 2012). Sponges are among the most diverse and ecologically important benthic organisms to reefs (Sarà and Vacelet 1973; Uriz and Turon 2012). Sponges are important to reef ecosystems as primary producers and bioeroders (Rützler 1975; Diaz and Rützler 2001). In addition, sponges increase overall habitat availability for reef microfauna (Beaulieu 2001; Rützler 2004; Henkel and Pawlik 2011). They remove organic matter from the reef and increase the cycling rate of carbon and important nutrients (Reiswig 1971; Pile et al. 1997; Diaz and Rützler 2001; Jiménez and Ribes 2007). Furthermore, having arisen in the Precambian era (Finks 1970; Li et al. 1998), sponges are among the most ancient metazoans, making them target organisms for evolutionary studies on such varied topics as speciation, cell and tissue development, and the origin of the immune system (Schütze et al. 1999; Müller and Müller 2003; Srivastava et al. 2010). Lastly, sponges produce important secondary metabolites for possible pharmaceutical applications (Munro et al. 1999; Mayer et al. 2010). Our understanding of the basics of sponge population ecology and genetics is thus crucial to understanding how sponge populations function, how they evolve, and how resilient they can be to perturbations that affect reef ecosystems. Like many benthic reef organisms, 
sponges have a complex life history with a juvenile larval stage and a sedentary adult stage. While a given sponge species might reproduce both sexually and asexually, sponge populations rely heavily on larval dispersal for genetic exchange (Maldonado and Uriz 1999; Maldonado 2006). Incorporating knowledge of genetic connectivity in sponges into the design of marine protected areas will be crucial for developing conservation schemes that will maintain ecosystem stability and diversity (McCook et al. 2009; Arrieta et al. 2010).

To broaden our knowledge of population genetics in sponges, we developed 12 new polymorphic microsatellite markers for a common reef sponge, Stylissa carteri (Table 1). $S$. carteri has a widespread distribution (Hooper and van Soest 2002) and has been found to be abundant in coastal Red Sea reefs typically between 5 and $15 \mathrm{~m}$ in depth (M.L.B. and E.C. G., unpublished data). As a member of the family Axinellidae, Stylissa carteri has indirect and external larval development (Maldonado 2006), and the morphology of the larva is most likely of the parenchymella form (Ereskovsky 2010). To date, genetic resources for sponges are extremely limited. For instance, microsatellite markers have only been characterized for eight species not including Stylissa carteri (Duran et al. 2002; Knowlton et al. 2003; Blanquer et al. 2005; Hoshino and Fujita 2006; Noyer et al. 2009; Dailianis and Tsigenopoulos 2010; Gigliarelli et al. 2010; Guardiola et al. 2011). The purpose of this study was to identify polymorphic loci that are informative for determining the population structure, connectivity patterns, and possible reproductive capabilities of $S$. carteri.

\section{Methods}

Sample collection, DNA extraction and sequencing

Samples of Stylissa carteri were collected by SCUBA at Fsar Reef $\left(22^{\circ} 23^{\prime} \mathrm{N} ; 39^{\circ} 03^{\prime} \mathrm{E}\right), n=24$, and Abu Shoosha Reef $\left(23^{\circ} 305^{\prime} \mathrm{N} ; 39^{\circ} 049^{\prime} \mathrm{E}\right), n=24$, in the central Red Sea at a depth between 5 and $15 \mathrm{~m}$. Samples were collected in November 2010, June 2012, and August 2012 and immediately placed in $70 \%$ ethanol and calcium-magnesium-free artificial seawater (CMF-ASW) upon surfacing. The sample taxonomy was verified as S. carteri by Nicole de Voogd at The Netherlands Centre for Biodiversity (NCB) Naturalis.

The total holobiont DNA was extracted from 200$250 \mathrm{mg}$ sponge tissue with an initial cell lysis step where the tissue was immersed in $600 \mu \mathrm{l}$ of $1 \% 2$-mercaptoethanol RLT buffer (Qiagen) and shaken using a FastPrep Instrument (MP Biomedicals). Following cell lysis, the DNA extraction method proceeded via the Allprep DNA/RNA mini Kit (Qiagen). The quality and quantity of extracted DNA was measured using a NanoDrop 8000 spectrophotometer (Thermo Scientific).

Next-generation sequencing was done for one S. carteri sample using a Roche 454 GS-FLX (titanium) sequencer at the King Abdullah University of Science and Technology Bioscience Core Lab. Over 2 million reads with an average length of $230 \mathrm{bp}$ were generated. Raw, unassembled reads were used to search for putative microsatellite loci.

Characterisation of microsatellite loci and PCR optimization

Microsatellites were mined from the generated 454 data using the software MSATCOMMANDER v 1.0.8 (Faircloth 2008) with Primer3 plug-in (Rozen and Skaletsky 2000). MSATCOMMANDER default settings were used for screening reads for perfect, dinucleotide motifs. A total of 2,417 putative microsatellite loci were obtained and 96 were selected for polymerase chain reaction (PCR) trials. PCR reactions were set up following protocols associated with the Multiplex PCR kit (QIAGEN). Primers were tested at annealing temperatures ranging from 55 to $63{ }^{\circ} \mathrm{C}$. PCR reaction volume was $10 \mu \mathrm{l}$, consisting of $5 \mu \mathrm{l}$ Multiplex Mix (Qiagen), $1 \mu \mathrm{l}$ primers $(2 \mu \mathrm{M}), 3 \mu \mathrm{l}$ water, and $1 \mu \mathrm{l}$ genomic DNA (30-100 ng/ $\mu \mathrm{l})$. PCRs were performed using an Applied Biosystems GeneAmp PCR 9700 system using the following parameters: $15 \mathrm{~min}$ at $95^{\circ} \mathrm{C}$, followed by 30 cycles of $30 \mathrm{~s}$ at $94{ }^{\circ} \mathrm{C}$, $90 \mathrm{~s}$ at $55-63{ }^{\circ} \mathrm{C}, 90 \mathrm{~s}$ at $72{ }^{\circ} \mathrm{C}$ and a final extension of $72{ }^{\circ} \mathrm{C}$ for $10 \mathrm{~min}$. The 96 designed primer pairs were first tested on eight samples to identify polymorphic loci. PCR products were run on a QIAxcel genetic analyzer (Qiagen) using a high-resolution cartridge to check for primer specificity (clean bands) and to identify polymorphic loci. Of the 96 loci tested, 31 showed clear unambiguous and polymorphic PCR bands. Primers for these loci were labeled with ABI fluorescent tags (6-FAM, PET, VIC, and NED) and PCRs were performed as described previously for all 48 samples. Diluted PCR products were mixed with Hi-Di formamide (Applied Biosystems) and GeneScan 500-LIZ size standard (Applied Biosystems) and run on an ABI 3730xl genetic analyser (Applied Biosystems). Microsatellite loci were scored using the software GENEMAPPER 4.0 (Applied Biosystems).

Data analysis

Allelic frequencies, number of alleles $(\mathrm{Na})$, observed $(\mathrm{Ho})$ and expected heterozygosities $(\mathrm{He})$ were estimated for each reef using the software Genalex $v$ 6.5. We tested for the presence of linkage disequilibrium and deviations from Hardy-Weinberg proportions using Genepop (Raymond and Rousset 1995; Rousset 2008). Genepop was also used to calculate Fis using the Weir and Cockerham estimate 


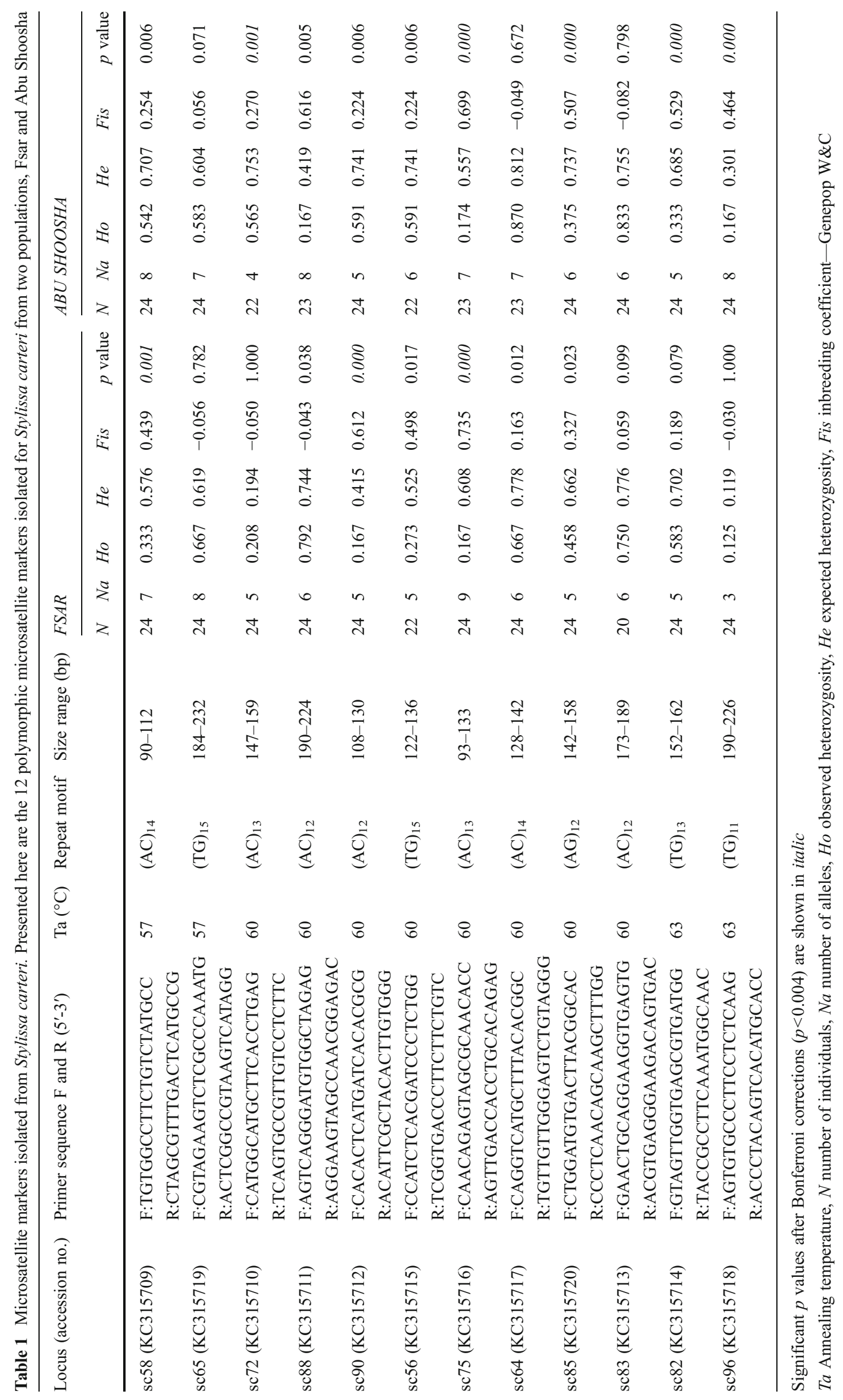


(Weir and Cockerham 1984). MICROCHECKER (Van Oosterhout et al. 2004) was used to verify if deviations from HWE could be explained by the presence of null alleles.

\section{Results and discussion}

Of the 31 primer pairs that were used to amplify all 48 samples, only 12 yielded clear fragment peaks that could be reliably scored and amplified in all samples. An average of 73.5 alleles (3-8 per loci/population) was found per population analyzed. None of the samples that were genotyped shared the same multilocus genotype, indicating the absence of clones within our samples. Observed heterozygosity frequencies $(\mathrm{Ho})$ ranged from 0.125 to 0.870 , while expected $\mathrm{He}$ ) heterozygosity frequencies ranged from 0.119 to 0.812 . Results from Genepop suggested that a total of seven loci deviated from Hardy-Weinberg equilibrium (HWE) after Bonferroni correction for at least one population (Fsar: sc58, sc90, sc75; Abu Shosha: sc72, sc75, sc85, sc82, sc96). However, only one locus (sc75) deviated from HWE in both populations $\left(p_{\mathrm{Fsar}}<0.001, p_{\text {abushosha }}<0.001\right)$. Results from MICROCHECKER showed the possible presence of null alleles for seven loci (Fsar: sc58, sc90, sc56, sc75; Abu Shoosha: sc90, sc75, sc85, sc82, sc96). Yet, only two of these loci showed consistent evidence for null alleles in both populations (sc90 and sc75). No significant linkage disequilibrium was detected for any pairs of loci $(\alpha=0.05)$.

While it is noted that several markers developed here showed deviations from HWE, the disparity of these deviations among populations in all but one locus (sc75) suggests that other contributing factors different from null alleles might be the cause of this phenomena. Deviations from HWE linked to reduced heterozygosities seem to be rather common in other sponge species (Duran et al. 2004a; Whalan et al. 2005; Duran and Rützler 2006; Noyer 2010; Guardiola et al. 2011; Uriz and Turon 2012), and might be a consequence of limited dispersal leading to inbreeding, the presence of clonality, or both, rather than the presence of null alleles. Overall, it seems that heterozygote deficits might be a natural trend of sponges and, in the case of this study, it does not seem to be an artifact due to primer binding errors. However, further studies are warranted to test these hypotheses in $S$. carteri. The markers described in this study will certainly provide a valuable tool for this purpose.

\section{Conclusion}

The 12 microsatellite markers developed here will make useful contributions to the future studies of sponge population genetics. Until now, microsatellites have only been developed for eight species within all the Porifera (Duran et al. 2002; Knowlton et al. 2003; Blanquer et al. 2005; Hoshino and Fujita 2006; Noyer et al. 2009; Dailianis and Tsigenopoulos 2010; Gigliarelli et al. 2010; Guardiola et al. 2011) and have only been used for population-wide analyses in few species (Duran et al. 2004a; Calderón et al. 2007; Hoshino et al. 2008; Blanquer et al. 2009; Blanquer and Uriz 2010, 2011; Noyer 2010; Dailianis et al. 2011; Guardiola et al. 2011). The highly variable markers presented herein will be useful for determining fine scale variability between sponge populations and tools for determining species identification for cryptic taxa within this group. Due to strong spatial structure reported in some sponges (Duran et al. 2004b; Blanquer and Uriz 2010), microsatellite markers will be especially important for making strong ecological and evolutionary inferences.

Acknowledgments This work was funded by the King Abdullah University of Science and Technology. We would like to thank Dr. Nicole de Voogd for taxonomic identification, Dr. Annika Haywood for help sampling in the field, the KAUST Genomics Core Lab for sample processing and two anonymous reviewers for constructive comments in a previous version of this manuscript.

Open Access This article is distributed under the terms of the Creative Commons Attribution License which permits any use, distribution, and reproduction in any medium, provided the original author(s) and the source are credited.

\section{References}

Arrieta JM, Arnaud-Haond S, Duarte CM (2010) What lies underneath: conserving the oceans' genetic resources. Proc Natl Acad Sci USA 107(43):18318-18324

Beaulieu SE (2001) Life on glass houses: sponge stalk communities in the deep sea. Mar Biol 138:803-817

Becerro MA (2008) Quantitative trends in sponge ecology research. Mar Ecol 29(2):167-177

Blanquer A, Uriz MJ (2010) Population genetics at three spatial scales of a rare sponge living in fragmented habitats. BMC Evol Biol 10:13

Blanquer A, Uriz MJ (2011) Living together apart: the hidden genetic diversity of sponge populations. Mol Biol Evol 28:2435-2438

Blanquer A, Uriz MJ, Pascual M (2005) Polymorphic microsatellite loci isolated from the marine sponge Scopalina lophyropoda (Demospongiae: Halichondrida). Mol Ecol Notes 5:466-468

Blanquer A, Uriz MJ, Caujapé-Castells J (2009) Small-scale spatial genetic structure in Scopalina lophyropoda, an encrusting sponge with philopatric larval dispersal and frequent fission and fusion events. Mar Ecol Prog Ser 380:95-102

Calderón I, Ortega N, Duran S, Becerro M, Pascual M, Turon X (2007) Finding the relevant scale: clonality and genetic structure in a marine invertebrate (Crambe crambe, Porifera). Mol Ecol 16:1799-1810

Dailianis T, Tsigenopoulos CS (2010) Characterization of polymorphic microsatellite markers for the endangered Mediterranean bath sponge Spongia officinalis L. Conserv Genet 11:155-1158

Dailianis T, Tsigenopoulos CS, Dounas C, Voultsiadou E (2011) Genetic diversity of the imperilled bath sponge Spongia officinalis 
Linnaeus, 1759 across the Mediterranean Sea: patterns of population differentiation and implications for taxonomy and conservation. Mol Ecol 20:3757-3772

Davies SW, Rahman M, Meyer E, Green EA, Buschiazzo E, Medina M, Matz MV (2012) Novel polymorphic microsatellite markers for population genetics of the endangered Caribbean star coral, Montastraea faveolata. Mar Biodiv

Diaz MC, Rützler K (2001) Sponges: an essential component of Caribbean coral reefs. Bull Mar Sci 69(2):535-546

Duran S, Rützler K (2006) Ecological speciation in a Caribbean marine sponge. Mol Phylogenet Evol 40:292-297

Duran S, Pascual M, Estoup A, Turon X (2002) Polymorphic microsatellite loci in the sponge Crambe crambe (Porifera: Poecilosclerida) and their variation in two distant populations. Mol Ecol Notes $2: 478-480$

Duran S, Pascual M, Estoup A, Turon X (2004a) Strong population structure in the marine sponge Crambe crambe (Poecilosclerida) as revealed by microsatellite markers. Mol Ecol 13:511-522

Duran S, Giribet G, Turon X (2004b) Phylogeographical history of the sponge Crambe crambe (Porifera, Poecilosclerida): range expansion and recent invasion of the Macaronesian islands from the Mediterranean Sea. Mol Ecol 13:109-122

Ereskovsky AV (2010) The comparative embryology of sponges. Springer, Chichester

Faircloth B (2008) MSATCOMMANDER: detection of microsatellite repeat arrays and automated, locus-specific primer design. Mol Ecol Resour 8:92-94

Finks RH (1970) The evolution and ecologie history of sponges during Palaeozoic times. Symp Zool Soc Lond 25:3-22

Gigliarelli L, Lucentini L, Palomba A, Bazzucchi E, Puletti M, Sgaravizzi G, Lancioni H, Lanfaloni L, Bruford M, Panara F (2010) Microsatellite markers in the freshwater sponge Ephydatia fluviatilis (Porifera: Spongillidae). Mol Ecol Resour 10(3):576579

Guardiola M, Frotscher J, Uriz MJ (2012) Genetic structure and differentiation at a short-time scale of the introduced calcareous sponge Paraleucilla magna to the western Mediterranean. Hydrobiologia 687:61-84

Henkel TP, Pawlik JR (2011) Host specialization of an obligate sponge-dwelling brittlestar. Aquatic Biol 12:37-46

Hooper JNA and WM Van Soest (2002) Systema Porifera: a guide to the classification of sponges 2: 724-730

Hoshino S, Fujita T (2006) Isolation of polymorphic microsatellite markers from Hymeniacidon sinapium (Porifera: Demospongiae: Halichondrida). Mol Ecol Notes 6:829-831

Hoshino S, Saito DS, Fujita T (2008) Contrasting genetic structure of two Pacific Hymeniacidon species. Hydrobiologia 603:313-326

Jiménez E, Ribes M (2007) Sponges as a source of dissolved inorganic nitrogen: nitrification mediated by temperate sponges. Limnol Oceanogr 52(3):948-958

Knowlton AL, Pierson BJ, Talbott SL, Highsmith RC (2003) Isolation and characterization of microsatellite loci in the intertidal sponge Halichondria panacea. Mol Ecol Notes 3:560-562

Li C, Chen J, Hua T (1998) Precambrian sponges with cellular structures. Science 279:879-882

Maldonado M (2006) The ecology of sponge larva. Can J Zool 84(2):175-194

Maldonado M, Uriz MJ (1999) Sexual propagation by sponge fragments. Nature 398:476

Mayer AMS, Glaser KB, Cuevas C, Jacobs RS, Kem W, Little RD, McIntosh JM, Newman DJ, Potts BC, Shuster DE (2010) The odyssey of marine pharmaceuticals: a current pipeline perspective. Trends Pharmacol Sci 31(6):255-265

McCook LJ, Almany GR, Berumen ML, Day JC, Green AL, Jones GP, Leis JM, Planes S, Russ GR, Sale PF, Thorrold SR (2009) Management under uncertainty: guide-lines for incorporating connectivity into the protection of coral reefs. Coral Reefs 28:353-366

Müller WEG, Müller IM (2003) Origin of the metazoan immune system: identification of the molecules and their functions in sponges. Integr Comp Biol 43(2):281-292

Munro MHG, Blunt JW, Dumdei EJ, Hickford SJH, Lill RE, Li S, Battershill CN, Duckworth AR (1999) The discovery and development of marine compounds with pharmaceutical potential. J Biotech 70:15-25

Noyer C (2010) Relationship between genetic, bacterial and chemical diversity of the Mediterranean sponge Spongia agaricina. $\mathrm{PhD}$ Thesis, University of Barcelona, Barcalona

Noyer C, Agell G, Pascual M, Becerro MA (2009) Isolation and characterization of microsatellite loci from the endangered Mediterranean sponge Spongia agaricina (Demospongiae: Dictyoceratida). Conserv Genet 10:1895-1898

Pile AJ, Patterson MR, Savarese M, Chernykh VI, Fialkov VA (1997) Trophic effects of sponge feeding within Lake Baikal's littoral zone. 2. Sponge abundance, diet, feeding efficiency, and carbon flux. Limnol Oceanogr 42(1):178-184

Raymond M, Rousset F (1995) An exact test for population differentiation. Evolution 49(6):1280-1283

Reiswig HM (1971) In situ pumping activities of tropical Demospongiae. Mar Biol 9:38-50

Rousset F (2008) Genepop'007: a complete re-implementation of the genepop software for Windows and Linux. Mol Ecol Resour 8(1):103-106

Rozen S, Skaletsky HJ (2000) Primer3 on the WWW for general users and for biologist programmers. In: Krawetz S, Misener S (eds) Bioinformatics methods and protocols: Methods in Molecular Biology. Humana Press, Totowa, pp 365-386

Rützler K (1975) The role of burrowing sponges in bioerosion. Oecologia 19:203-216

Rutzler K (2004) Sponges on coral reefs: a community shaped by competitive cooperation. Bollettino Dei MuseiIstituti Biologici 68:85-148

Sarà M and J Vacelet (1973) Écologie des démosponges. Traité de Zoologie. Anatomie, Systématique, Biologie. III Spongiares: $462-576$.

Schütze J, Krasko A, Custodio MR, Efremova SM, Mller IM, Müller WEG (1999) Evolutionary relationships of Metazoa within the eukaryotes based on molecular data from Porifera. Proc Biol Sci 266(1414):63-73

Srivastava M et al (2010) The Amphimedon queenslandica genome and the evolution of animal complexity. Nature 466(7307):720-726

Uriz MJ, Turon X (2012) Sponge ecology in the molecular era. Adv Mar Biol 61:345-410

Van Oosterhout C, Hutchinson WF, Wills DPM, Shipley P (2004) MicroChecker: software for identifying and correcting genotyping errors in microsatellite data. Mol Ecol Resour 4:535-538

Van Oppen M, Gates R (2006) Conservation genetics and the resilience of reef-building corals. Mol Ecol 13:3863-3883

Weir BS, Cockerham CC (1984) Estimating F-statistics for the analysis of population structure. Evolution 38(6):1358-1370

Whalan S, Johnson MS, Harvey E, Battershill C (2005) Mode of reproduction, recruitment, and genetic subdivision in the brooding sponge Haliclona sp. Mar Biol 146:425-433 